\title{
Later-generation Descendants of Immigrants and Scholastic Effort
}

\author{
Giuseppina Autiero ${ }^{1} \&$ Annamaria Nese ${ }^{1, *}$ \\ ${ }^{1}$ Department of Economics and Statistics, University of Salerno, Salerno, Italy \\ *Correspondence: Department of Economics and Statistics, University of Salerno, Via Giovanni Paolo II, 132-84084 \\ Fisciano (SA), Italy. E-mail: anese@unisa.it
}

Received: April 15, 2020 Accepted: October 29, 2020 Online Published: January 15, 2021

doi:10.5430/wjss.v8n1p52 URL: https://doi.org/10.5430/wjss.v8n1p52

\begin{abstract}
Later-generation descendants of immigrants generally negotiate their heritage and mainstream culture, and all the factors that affect the mediation play a crucial role. During early adolescence, the extent to which individuals may identify with the two cultures is largely determined by the attitudes of family towards integration and the attitudes of host countries in terms, for instance, of social rejection. We empirically assess the influence of heritage and dominant culture on teens' scholastic effort and attitude towards school. The analysis relies on a sample of teens aged 14, born in the UK between 2000 and 2002; the data are drawn from the Millennium Cohort Study Sixth Sweep. The results show that ethnic background along with religion count and that the experience of social rejection has a negative influence. Overall, the evidence shows the possibility that all the factors that help the mediation between ethnic background and mainstream culture by promoting the development of a cohesive identity foster the motivation of scholastic effort.
\end{abstract}

Keywords: scholastic effort, attitude towards school, ethnicity, microeconometrics

JEL classifications: I20, I29, Z10

\section{Introduction}

It has recently developed a strand of literature that shows the significant role ethnic background of immigrants plays in their children's academic performance. For instance, Schüller (2011) explains how in Germany mothers' identification with host country and fathers' identification with home country foster scholastic performance of second-generation children. Nekby, Rödin and Özcan (2009) illustrate the evidence that in Sweden men with an integrated identity-who are attached both to their home background and to the majority culture-have a higher probability of completing tertiary education. Siahaan et al. (2014) find out that second-generation children of immigrants-U.S.-born children-and foreign-born children with both immigrant parents attain higher education than the other groups of immigrants and natives because of the importance attached to education by their parents. Dustmann and Theodoropoulos (2010), examining the educational and employment performances of minority groups, underline that British-born children of immigrants fare better than natives in terms of educational attainments. Meunier et al. (2013), using data from a cohort born in 1970 of second-generation children in the UK, find that most ethnic minority groups have lower scholastic achievements in primary school, particularly those with South Asian or Afro-Caribbean background, but some of them -namely those from South Asia- show signs of catch-up; overall, ethnic minorities in England go on catching up with their white counterparts in secondary school.

This part of the literature has led to the widespread view that ethnic background matters in education; nevertheless, when one considers later-generation descendants of immigrants, differently from their parents who had to adjust to a foreign setting, they are exposed to the new culture to a greater extent. This implies that they generally negotiate home cultural heritage and mainstream culture and all the factors that affect the mediation between ethnic background and mainstream culture play a crucial role.

Why can this aspect be so important in the context of education? This contribution aims to shed some light on the answer to this question by extending the literature as in our view the identification with ethnic and majority culture may affect children's motivation to exert effort in school and some of the mediating factors such as family background and social relationships are important. During the early adolescence in fact the extent to which individuals may identify with the two cultures is largely determined by the attitudes of family towards integration and the attitudes of host 
countries in terms, for instance, of social rejection. In this respect, we previously uncovered a role for ethnic identity in children's scholastic effort (Autiero \& Nese, 2017) and the current work builds on this study as it explicitly focuses on later-generation descendants of immigrants and on empirical measures of scholastic effort.

We consider a sample of teens aged 14, born in the UK between 2000 and 2002; the sample is drawn from the Millennium Cohort Study Sixth Sweep as this survey collects information crucial for our analysis such as scholastic effort, attitude to school, family socio-economic background, relationships with parents and friends. Hence it in particular allows to focus on effort and interest in school as opposed to achievement alone. Accordingly, in the remainder of the paper, we review the psychological and economic literature on the factors influencing the mediation between individuals' attachment to their ethnic culture and to the culture of the receiving society and thereby scholastic motivations and effort in $\S 2$; in $\S 3$ we describe the dataset and present an empirical model predicting scholastic effort and attitude towards school, $\S 4$ contains the discussion of the results followed by the conclusions.

\section{Heritage Culture, Majority Culture and Children's Motivation to Exert Scholastic Effort}

When immigrant people come into contact with a new receiving society, they undergo a change in their cultural identity through a process of adaptation which takes the form of acculturation. According to the psychological literature, acculturation presents two aspects: the former consists in the adoption of the values, beliefs and practices of the mainstream culture, the latter in the preservation of the values, beliefs and practices of the heritage culture.

Berry (2005) depicts individuals' acculturation strategies in terms of integration, assimilation, separation and marginalization: integrated individuals prefer to preserve aspects of both their own and host culture while with assimilation they solely integrate into host culture; in the case of separation, they tend to preserve only their home culture whereas marginalization means rejection of both cultures.

The extent to which immigrants absorb the culture of the receiving society and either discard or retain their own culture depends on the closeness between the two cultures (Rudmin, 2003), the experience of social rejection (Brown, 2000), the attitudes of the host societies towards immigrants' culture (Portes \& Rumbaut, 2001), the flexibility of heritage culture to adjust to the new culture (Jensen, 2003).

If acculturation implies that immigrants tend to learn dominant culture when they move to host countries, in the case of later generations of native born, they simultaneously learn both cultures and biculturation appears to be more appropriate (Huynh, Nguyen \& Benet-Martínez, 2011). Also in the case of biculturalism, the divergence between the two cultures plays an important role (Rudmin, 2003). Differences in how individuals negotiate ethnic and mainstream culture lead to various degrees of bicultural identity integration depending on the perception of discrepancies between them. They may be considered as either distant and incongruent and therefore difficult to integrate or similar and coherent (Benet-Martínez, Leu, Lee \& Morris, 2002; Benet-Martínez \& Haritatos, 2005). Strained relations, social rejection and discrimination can fuel the perception of discrepancies and hamper the achievement of a cohesive bicultural identity. When there is tension between mainstream and home culture, individuals often behave in contrast to dominant culture; in the latter respect, Fordham and Ogbu (1986) argue that African Americans often tend to develop their ethnic identity in opposition to the dominant group and to preserve it from integration into the mainstream culture as their identity is rooted in the experience of discrimination.

In the domain of family incongruities may often concern the obligations regarding the relationship between parents and children; youth may prefer an acculturation strategy, which may be source of different views on the responsibility for various chores from their parents who are more attached to their home culture. This is frequent in families with conservative religious values and the clash between parents' and children's orientations may lead to poorer sociocultural adaptation of youth (Berry 2005).

Relatedly, a recent strand of the economic literature drawing on social sciences has paid particular attention to the process of transmission of cultural traits as they shape how individuals frame and react to a common environment. Whether ethnic minorities retain their cultural traits or prefer an assimilation strategy depends on direct socialization through family purposeful choice and socialization through social connectedness in mainstream society and ethnic community.

Konya (2005) and Lazear (1999) consider altruistic parents who take into account the gains from assimilation accruing to their children. Analogously parents' effort choices of transmitting their own cultural traits on to their children depends on the evaluation of costs and benefits related to the specific socio-economic context they face; it may be such to lead family to socialize children to majority culture in order to expand their social opportunities (Bisin \& Verdier, $2000,2001,2011)$. Parents' socialization to their own cultural traits can be either reinforced or weakened by teachers in 
school, peers and members of their ethnic community; for this reason parents tend to shape also their children's cultural and social environment and to this aim often choose school, neighbourhoods and peers for them (Bisin \& Verdier, 2011). Interestingly, Giavazzi, Petkov and Schiantarelli (2019) show that the more persistent cultural traits are those directly transmitted within the family. Children after parental socialization to the cultural traits of a minority, may also choose the extent to which they identify with their home culture and their decision may be affected by the ethnic composition of their neighbourhood and the experience of social rejection among other things (Bisin, Patacchini, Verdier \& Zenou, 2016).

This paper builds on the literature described above and on the consideration that later generations of immigrants may, on the one hand, absorb the culture of the receiving society to some extent and, on the other, retain some cultural traits of their ethnic background. Our objective is to analyse the type of relationship between teen's identification with home and mainstream cultures and their motivations to exert effort in school in line with Autiero and Nese (2017).

Specifically, we argue that children under their parents' influence may follow a path of adaptation to mainstream culture based on the internalization of values giving importance to education as a means, for instance, to climb the social ladder. The value parents give to education may depend not only on their orientation to adjustment to the receiving society but on their ethnic background as well (Yasui \& Dishion, 2007). In this respect, it is also crucial that parents perceive their own ethnic background and majority culture as congruent. This entails that they are able to transmit the importance of acquiring education even when it is rooted in a rather different culture and to nurture their children's motivation to exert effort in school.

Whereas discrepant cultures often are source of internal conflicts weakening adjustment ability of individuals. Internal conflicts occur also when dominant groups' orientations toward immigrants are characterised by ethnic prejudices and stereotyping, which may translate into strained relations and social rejection. The final effect is that the perceived gap between heritage and dominant culture widens (Berry, 2005; Nguyen \& Benet-Martínez, 2013), which is transmitted by parents on to their children and finding the right motivation to engage in academic tasks becomes hard. Importantly attitudes of ethnic community's peers may affect children's motivation to exert effort in a similar way (Portes \& Zhou, 1993).

\section{Specification of the Empirical Model}

The empirical analysis relies on variables drawn from the Millennium Cohort Study Sixth Sweep (henceforth MCS6), comprising detailed information on a large sample of young individuals born in the UK between 2000 and 2002; our focus is on the sample drawn from England as in Wales, Scotland and Northern Ireland ethnic minorities form a low percentage of the population (Note 1).

The MCS used a stratified, clustered random sample design and oversampled from areas that were disadvantaged and with high ethnic minority groups; this was to permit robust inference about the effect of poor economic conditions on teens, as well as about ethnic minorities.

In the sample, teens represent later-generation descendants of immigrants (Note 2), who simultaneously learn both their home and mainstream culture. In our previous paper (Autiero \& Nese, 2017), where we assessed the influence of ethnic identity on children's scholastic effort, the 1970 British Cohort Study data included both first-generation immigrants and later-generation descendants and was characterised by a limited number of observations for ethnic minorities, which did not ensure conclusive evidence. Importantly, considering later generations attenuates problems of selection into immigration (Note 3) and weakens the role of some confounding factors characterising first-generation immigrants who may find it difficult to speak a foreign language and still nurture strong ties with non-immigrating family members (Fernàndez, 2008, 2010).

We chose this survey for different reasons: the main one is that the MCS6 sample permits an extension of our preceding research as it makes explicit empirical measures of scholastic effort on a relatively wider sample of later immigrants' descendants available. Moreover, it concerns a country characterized by the coexistence of several ethnic groups and collects information crucial for our analysis such as scholastic effort, attitude to school, family socio-economic background, relationships with parents and friends; this information is provided by teenagers or in some cases by their parents. Finally, the data are collected in a series of waves throughout the participants' lives: at birth, three, five, seven, eleven, fourteen years.

Our analysis is mainly based on the survey at age fourteen since mid-teens are in a critical stage for their personality development: the school leaving age is becoming closer, after which they have to decide between academic or vocational education, relationships with parents and peers change. Importantly, at this age teens' attitudes are still 
influenced by their parents' socialization strategy to their own ethnic background and to majority culture so that that their attachment to the two culture may result from the transmission of cultural traits within the family. We also draw on information from the third sweep -when sampled individuals were aged five-about children exogenous abilities evaluated according to the British Ability Scales.

We assume that individual optimal effort $\mathrm{e}^{*}$ depends on certain measurable factors $\mathrm{x}$ and unobserved factors $\varepsilon$ such that:

$$
e_{i}^{*}=\beta^{\prime} x_{i}+\varepsilon_{i}
$$

Whereas previous studies in this field measures scholastic effort as the probability that children will continue education beyond a specific stage or as attitude towards school (Note 4) (Autiero \& O'Higgins, 2016), in this work we rely on empirical measures of scholastic effort. More precisely, during the MCS6 sampled individuals aged fourteen were asked the following questions: 1) How often do you try your best at school?; 2) How often do you find school interesting?; 3) How often do you feel school as a waste of time?; 4) How often do you find it difficult to keep your mind on your work at school? Four possible answers were given, on a scale 0-3: all of time, most of time, some of the time, never.

Hence, first we estimate an ordered probit model where the dependent variable $e_{i}^{*}$-Effort-is drawn from the answers to the first question above; the empirical measure of effort is as follows:

$e_{i}=0 \quad$ if $\mathrm{e}_{\mathrm{i}}^{*} \leq 0$,

$e_{i}=1 \quad$ if $\quad 0<\mathrm{e}_{\mathrm{i}}^{*} \leq \alpha_{1}$,

$e_{i}=2$ if $\alpha_{1}<\mathrm{e}_{1}^{*} \leq \alpha_{2}$,

$e_{i}=3 \quad$ if $\quad \alpha_{2} \leq \mathrm{e}_{\mathrm{i}}^{*}$

where the $\alpha$ 's are the unknown threshold parameters and the stochastic term $\varepsilon$ is normally distributed with mean 0 and variance 1(Note 5).Second, we estimate a linear regression model where the dependent variable relies on all the four questions above. Students' trying their best, academic interest and capacity of attention at school in fact are driven by motivation, which underpins learning orientations. Hence, the empirical model is as follows:

$$
s_{i}=\gamma^{\prime} w_{i}+\mu_{i}
$$

Where the dependent variable is an index-named Attitude towards school-obtained by adding the scores reported for each of the four questions above and varying between 0 and 12 (Note 6); higher values indicate more positive attitude.

In the estimation procedure, we applied the design weights provided in the dataset in order to correct for differences in sampling.

On the one hand, we single out factors shaping ethnic cultural background, though we are aware that dummies for minority groups may embody aspects other than cultural values such as the ones that led some groups to select into migration (e.g. economic reasons, related political instability). As specified above, considering later-generation descendants of immigrants attenuates this concern, whereas the inclusion of parental background-income and education-among correlates may capture economic and institutional differences across countries of ancestry among other things (Note 7). On the other hand, as individuals face a culture different from their ethnic background and have to mediate between them, we take into account variables embodying their response to English culture and affecting their motivation to exert scholastic effort.

As to ethnic background, Ethnicity corresponds to dummy variables, nominally UK, White background other than English (Non-UK White), Mixed comprising White and Black Caribbean, White and Black African, White and Asian, any other mixed ethnic background, Gypsy-as defined in the survey, Indian, Pakistani, Bangladeshi, Chinese, any other Asian background (Other Asians), Black including Black/ African/ Caribbean/ Black British, Arab, any other ethnic group (Other ethnic groups). Religion identifies the affiliation of teens to Christian, Muslim, Hindu, Sikh, Jewish, Buddhist religion, no religion and to other religions whereas Religious Attendance indicates how often they attend religious services.

Language at Home indicates to what extent English is usually spoken at home ranging from only English, mostly English and sometimes other languages to only other languages, whereas Language with friends reveals whether the respondent does not speak English with friends, and may reflect ethnic heterogeneity in teens' neighbourhood or school; both variables are taken as teens' attachment to either their ethnic culture or English culture that, in our opinion, at age of fourteen are largely influenced by parents' choices. Similarly English language mastery of teens and parents reflecting the degree of integration in the host country- is represented respectively the variables Teens' word test and 
Parents' word test (Note 8); in the later, however we will not interpret the coefficient on Teens' word test as causally since proficiency in English and attitude towards school may depend on the same underlying factors.

Victim and Wellschool capture the relationship between the external environment and adaptation orientations, as the former is a dummy variable indicating whether anyone insulted, shouted at the respondent in a public place, at school or elsewhere in the last 12 months, therefore it embodies also the phenomenon of social rejection and discrimination. The latter shows how happy the respondent feels about the school where s/he goes to and can also describe schools' attitudes towards acculturating individuals; in fact, the quality of social relationships in school arena is crucial for the development of the feeling of belonging to school (Matthews, Banerjee \& Lauermann, 2014) and to English culture.

The influence of family, friends and peers is important as well, in this respect, Peerhard and Peertrouble are the proportions of close friends working hard and getting into trouble at school respectively, which allow to take into account the relation between peers' behaviour and teen's attitudes towards English culture and scholastic engagement; the coefficients on these variables however can hardly be interpreted causally because of the reflection problem (Manski, 1993).

Table 1a. Summary Statistics - Main Variables

\begin{tabular}{|c|c|c|c|}
\hline Variable & Variable definition & $\begin{array}{l}\text { Whole sample } \\
\text { Mean (SE) }\end{array}$ & $\begin{array}{l}\text { non UK } \\
\text { Mean (SE) }\end{array}$ \\
\hline Scholastic effort & $\begin{array}{l}\text { Dependent variable: indicates teenager } \\
\text { scholastic effort from the minimum, } \mathrm{e}_{\mathrm{i}}=0 \text { to the } \\
\text { maximum, } \mathrm{e}_{\mathrm{i}}=3 \text {. }\end{array}$ & $2.203(0.007)$ & $2.222(0.015)$ \\
\hline Attitude towards school & $\begin{array}{l}\text { Dependent variable: indicates teenager attitude } \\
\text { to school from the minimum, } \mathrm{a}_{\mathrm{i}}=0 \text { to the } \\
\text { maximum } \mathrm{a}_{\mathrm{i}}=12\end{array}$ & $7.786(0.024)$ & $7.795(0.054)$ \\
\hline Age & & $13.771(0.005)$ & $13.755(0.01)$ \\
\hline Religious attendance & $\begin{array}{l}\text { Indicates on a scale } 1 \text { (never), } 6 \text { (most days) } \\
\text { whether he/she attends a religious service }\end{array}$ & $5.038(0.017)$ & $3.3789(0.043)$ \\
\hline Homework & $\begin{array}{l}\text { Reveals how often - on a scale } 0 \text { (never), } 3 \\
\text { (always) - anyone (presumably, mother or } \\
\text { father) at home makes sure he/she did his/her } \\
\text { home works. }\end{array}$ & $2.131(0.111)$ & $2.059(0.022)$ \\
\hline Income & Family yearly income in quintiles $(1, . .5)$ & $2.991(0.016)$ & $2.341(0.032)$ \\
\hline Language at home & $\begin{array}{l}\text { Language spoken at home: equal to } 1 \text { if English } \\
\text { only; } 5 \text { if another language without English. }\end{array}$ & $1.212(0.008)$ & $1.906(0.028)$ \\
\hline Wellschool/ & How happy is the respondent with & $2.682(0.018)$ & $2.646(0.038) /$ \\
\hline Wellfriends/ & school/friends/family on a scale 0 (not at all), 6 & $2.143(0.015)$ & $2.111(0.033) /$ \\
\hline Wellfamily & (completely happy) & $2.102(0.016)$ & $2.088(0.034)$ \\
\hline Peerhard & $\begin{array}{l}\text { Proportions of close friends working hard: it } \\
\text { ranges from } 0 \text { (none of them) to } 3 \text { (most of } \\
\text { them). }\end{array}$ & $2.118(0.008)$ & $2.066(0.017)$ \\
\hline Peertrouble & $\begin{array}{l}\text { Proportions of close friends and getting into } \\
\text { troubles: it ranges from } 0 \text { (none of them) to } 3 \\
\text { (most of them). }\end{array}$ & $3.178(0.008)$ & $3.172(0.016)$ \\
\hline Mother word test & Tests measuring parents' understanding of the & $10.649(0.046)$ & $10.436(0.068)$ \\
\hline Father word test & meaning of words on a scale $0-19$ & $11.827(0.058)$ & $11.561(0.071)$ \\
\hline Teens word test & $\begin{array}{l}\text { Cognitive assessment at age } 14 \text { : it measures } \\
\text { understanding of the meaning of words on a } \\
\text { scale } 0-19\end{array}$ & $7.991(0.022)$ & $7.17(0.022)$ \\
\hline Female & $\begin{array}{l}\text { Dummy equal to } 1 \text { if the respondent is female, } \\
0 \text { otherwise }\end{array}$ & $\begin{array}{l}\text { Percentages } \\
50.02\end{array}$ & $\begin{array}{l}\text { Percentages } \\
50.30\end{array}$ \\
\hline Ethnic Group & Dummies for the respondent's Ethnic group & & \\
\hline UK & & 70.61 & - \\
\hline Gypsy & & 0.14 & 0.46 \\
\hline
\end{tabular}




\begin{tabular}{|c|c|c|c|}
\hline Non -UK White & & 0.69 & 2.79 \\
\hline Mixed & & 6.18 & 21.00 \\
\hline Pakistani & & 7.43 & 25.29 \\
\hline Bangladeshi & & 3.31 & 11.26 \\
\hline Other Asians & & 1.27 & 4.34 \\
\hline Black & & 4.61 & 15.70 \\
\hline Arab & & 1.18 & 3.97 \\
\hline Chinese & & 0.23 & 0.78 \\
\hline Indian & & 4.00 & 13.61 \\
\hline Other Ethnic groups & & 0.37 & 1.25 \\
\hline Religion & Dummies for religious background & & \\
\hline No religion & & 49.84 & 15.14 \\
\hline Christian & & 29.95 & 21.23 \\
\hline Muslim & & 14.38 & 48.50 \\
\hline Buddhist & & 0.26 & 0.55 \\
\hline Hindu & & 2.32 & 7.89 \\
\hline Jewish & & 0.24 & \\
\hline Sikh & & 1.57 & 5.31 \\
\hline Other religions & & 0.85 & 0.83 \\
\hline $\begin{array}{l}\text { No answer/vague/irrelevant } \\
\text { answer }\end{array}$ & & 0.59 & 0.41 \\
\hline Victim & $\begin{array}{l}\text { Dummy equal to } 0 \text { if the respondent was never } \\
\text { insulted, shouted at in a public place, at school } \\
\text { or elsewhere in the last } 12 \text { months, } 1 \text { otherwise }\end{array}$ & 57.42 & 67.37 \\
\hline Language with friends & $\begin{array}{l}\text { Dummy variable equal to } 1 \text { if the respondent } \\
\text { usually does not speak English with friends, } 0 \\
\text { otherwise. }\end{array}$ & 0.75 & 2.36 \\
\hline
\end{tabular}

Table 1b. Summary Statistics- Ethnic Groups and Religious Backgrounds (\%)

\begin{tabular}{|c|c|c|c|c|c|c|c|c|c|c|}
\hline Ethnic group & $\begin{array}{l}\text { No } \\
\text { religion }\end{array}$ & Christian & Buddhist & Hindu & Jewish & Muslim & Sikh & $\begin{array}{l}\text { Any } \\
\text { other }\end{array}$ & $\begin{array}{l}\text { Don't } \\
\text { know }\end{array}$ & Tot. \\
\hline UK & 64.30 & 33.59 & 0.13 & 0 & 0.31 & 0.19 & 0.02 & 0.86 & 0.36 & 100 \\
\hline Gypsy & 0.4 & 0.5 & 0 & 0 & 0 & 0.1 & 0 & 0 & 0 & 100 \\
\hline Non-English White & 39.21 & 50.98 & 0 & 0 & 0 & 1.96 & 1.96 & 3.92 & 1.96 & 100 \\
\hline Mixed & 43.64 & 36.62 & 0.44 & 1.09 & 0.22 & 14.69 & 1.10 & 1.54 & 0.66 & 100 \\
\hline Indian & 7.46 & 2.37 & 0.34 & 37.63 & 0 & 13.56 & 36.95 & 1.35 & 0 & 100 \\
\hline Pakistan & 0.18 & 0.18 & 0.18 & 0 & 0 & 99.09 & 0 & 0.18 & 0 & 100 \\
\hline Bangladeshi & 1.23 & 0 & 0 & 0 & 0 & 98.36 & 0 & 0 & 0.41 & 100 \\
\hline Chinese & 64.70 & 17.64 & 11.76 & 0 & 0 & 5.88 & 0 & 0 & 0 & 100 \\
\hline Other Asians & 2.12 & 6.38 & 5.32 & 55.32 & 0 & 29.79 & 1.06 & 0 & 0 & 100 \\
\hline Black & 0.1 & 65.29 & 0.29 & 0.29 & 0 & 22.35 & 0 & 1.18 & 0.59 & 100 \\
\hline Arab & 28.73 & 10.34 & 0 & 2.29 & 1.15 & 57.47 & 0 & 0 & 0 & 100 \\
\hline Other ethnic groups & 25.93 & 59.26 & 0 & 0 & 0 & 14.81 & 0 & 0 & 0 & 100 \\
\hline
\end{tabular}

We also consider wellbeing of adolescents with their friends and parents-Wellfriends and Wellfamily respectively -in order to capture any form of discomfort, which may also be caused by parent-child and children conflicts related to different orientations towards dominant culture.

Homework measures family involvement in children's education in general as it shows how often anyone at homepresumably, mother or father- makes sure their children did their homework. Nevertheless, it is not mistaken to hold 
that when one considers the subsample of ethnic groups, this variable may also embody acculturation orientations of parents. They shape their offspring's identity through the transmission of the importance of adaptation through schooling, perceived as important to climb the social ladder.

Family Income and Parents education capture any other factor influencing parents' interest in their children's scholastic effort.

\section{Results}

Table 2. Ordered Probit Estimates of Scholastic Effort-Whole Sample

\begin{tabular}{|c|c|c|c|c|c|c|}
\hline & I & II & III & IV & $\mathrm{V}$ & VI \\
\hline Age & $-0.034(0.035)$ & $-0.031(0.034)$ & $-0.032(0.035)$ & $-0.022(0.035)$ & $-0.017(0.036)$ & $-0.011(0.035)$ \\
\hline Female & $0.201 * * *(0.032)$ & $0.189^{* * *}(0.032)$ & $0.189^{* * *}(0.032)$ & $0.107 * * *(0.033)$ & $0.138 * * *(0.033)$ & $0.155^{* * *}(0.033)$ \\
\hline Homework & $0.264 * * *(0.018)$ & $0.259 * * *(0.018)$ & $0.258 * * *(0.018)$ & $0.217 * * *(0.018)$ & $0.194 * * *(0.018)$ & $0.190 * * *(0.018)$ \\
\hline \multicolumn{7}{|l|}{ Ethnic group: } \\
\hline White & $0.007(0.160)$ & $-0.017(0.161)$ & $-0.020(0.161)$ & $0.059(0.170)$ & $0.041(0.169)$ & $0.029(0.169)$ \\
\hline Gipsy & $-0.246(0.360)$ & $-0.270(0.357)$ & $-0.261(0.358)$ & $-0.220(0.304)$ & $-0.235(0.299)$ & $-0.168(0.276)$ \\
\hline Mixed & $-0.022(0.071)$ & $-0.049(0.073)$ & $-0.048(0.073)$ & $-0.050(0.074)$ & $-0.038(0.074)$ & $-0.035(0.073)$ \\
\hline Bangladeshi & $-0.092(0.117)$ & $-0.179(0.162)$ & $-0.172(0.163)$ & $-0.206(0.166)$ & $-0.199(0.164)$ & $-0.185(0.163)$ \\
\hline Chinese & $0.588 *(0.324)$ & $0.691 * *(0.329)$ & $0.690^{* *}(0.329)$ & $0.733^{* *}(0.372)$ & $0.778^{* *}(0.383)$ & $0.631 *(0.372)$ \\
\hline Pakistani & $0.073(0.094)$ & $-0.034(0.150)$ & $-0.026(0.151)$ & $-0.041(0.154)$ & $-0.024(0.151)$ & $-0.021(0.153)$ \\
\hline Indian & $0.364 * * *(0.103)$ & $0.200(0.172)$ & $0.199(0.173)$ & $0.210(0.171)$ & $0.200(0.166)$ & $0.162(0.166)$ \\
\hline Other Asians & $0.231(0.191)$ & $0.081(0.206)$ & $0.081(0.207)$ & $0.023(0.195)$ & $0.050(0.189)$ & $0.027(0.191)$ \\
\hline Arab & $-0.066(0.132)$ & $-0.097(0.141)$ & $-0.092(0.143)$ & $-0.085(0.153)$ & $-0.077(0.151)$ & $-0.035(0.156)$ \\
\hline Black & $-0.270 * * *(0.091)$ & $-0.355^{* * *}(0.093)$ & $-0.349 * * *(0.093)$ & $-0.357 * * *(0.098)$ & $-0.340 * * *(0.095)$ & $-0.296 * * *(0.096)$ \\
\hline Other Ethnic & $-0.185(0.227)$ & $-0.233(0.223)$ & $-0.241(0.223)$ & $-0.345(0.233)$ & $-0.336(0.229)$ & $-0.363(0.228)$ \\
\hline Victim & $-0.213 * * *(0.033)$ & $-0.212 * * *(0.033)$ & $-0.212 * * *(0.033)$ & $-0.139 * * *(0.033)$ & $-0.105 * *(0.033)$ & $-0.079 * *(0.033)$ \\
\hline Language at home & $1.132 * *(0.358)$ & $1.134 * *(0.367)$ & $1.134 * *(0.368)$ & $1.171 * *(0.368)$ & $1.105 * *(0.363)$ & $1.207 * *(0.399)$ \\
\hline Language with friends & $0.055(0.037)$ & $0.033(0.036)$ & $0.033(0.036)$ & $0.032(0.036)$ & $0.033(0.036)$ & $0.039(0.035)$ \\
\hline Home*with friends & $-0.266^{* *}(0.129)$ & $-0.271 * *(0.131)$ & $-0.271 * *(0.129)$ & $-0.257 * *(0.127)$ & $-0.260 * *(0.124)$ & $-0.293 * *(0.133)$ \\
\hline Parents word test & $0.019 * *(0.009)$ & $0.018 * *(0.009)$ & $0.015 *(0.009)$ & $0.004(0.009)$ & $0.006(0.009)$ & $0.004(0.009)$ \\
\hline Teens word test & $0.014 * *(0.007)$ & $0.013 *(0.007)$ & $0.012 *(0.007)$ & $-0.003(0.007)$ & $-0.002(0.007)$ & $-0.005(0.007)$ \\
\hline Religious attend. & & $0.022(0.014)$ & $0.022(0.015)$ & $0.014(0.015)$ & $0.012(0.014)$ & $0.006(0.015)$ \\
\hline \multicolumn{7}{|l|}{ Religion: } \\
\hline Christian & & $0.095 * *(0.042)$ & $0.093 * *(0.041)$ & $0.099 * *(0.042)$ & $0.095 * *(0.042)$ & $0.079 *(0.042)$ \\
\hline Muslim & & $0.111(0.148)$ & $0.115(0.148)$ & $0.061(0.152)$ & $0.018(0.151)$ & $-0.022(0.152)$ \\
\hline Buddhist & & $-0.546 *(0.332)$ & $-0.547 *(0.334)$ & $-0.669 * *(0.315)$ & $-0.682 * *(0.335)$ & $-0.439(0.324)$ \\
\hline Jewish & & $0.074(0.259)$ & $0.066(0.269)$ & $0.167(0.305)$ & $0.201(0.287)$ & $0.166(0.296)$ \\
\hline Hindu & & $0.339 *(0.195)$ & $0.329 *(0.195)$ & $0.265(0.193)$ & $0.272(0.188)$ & $0.250(0.188)$ \\
\hline Sikh & & $0.168(0.209)$ & $0.166(0.211)$ & $0.107(0.216)$ & $0.116(0.209)$ & $0.112(0.216)$ \\
\hline Other religions & & $0.057(0.144)$ & $0.059(0.147)$ & $0.095(0.169)$ & $0.072(0.160)$ & $0.049(0.162)$ \\
\hline Income & & & $0.011(0.014)$ & $-0.015(0.014)$ & $-0.014(0.014)$ & $0.024 *(0.014)$ \\
\hline Peertrouble & & & & $-0.342 * * *(0.020)$ & $-0.331 * * *(0.020)$ & $-0.311 * * *(0.020)$ \\
\hline Peerhard & & & & $0.343 * * *(0.020)$ & $0.327 * * *(0.020)$ & $0.311 * * *(0.020)$ \\
\hline Wellfriends & & & & & $0.082 * * *(0.016$ & $0.027(0.017)$ \\
\hline Wellfamily & & & & & & $0.061 * * *(0.016)$ \\
\hline Wellschool & & & & & & $0.115 * * *(0.014)$ \\
\hline N. observations & 7910 & 7910 & 7910 & 7910 & 7910 & 7910 \\
\hline N. parameters & 24 & 34 & 35 & 39 & 42 & 43 \\
\hline Log-lik. & -7029.211 & -7011.909 & -7011.438 & -6714.902 & -6661.300 & -6589.916 \\
\hline Wald & 406.48 & 437.28 & 437.99 & 761.92 & 852.90 & 959.61 \\
\hline
\end{tabular}

Notes: See Table 1 for the meaning of the variables. The reference group for ethnicity is UK; the reference group for religion is No religion. ${ }^{*} \mathrm{p}<0.10 ;{ }^{* *} \mathrm{p}<0.05 . * * * \mathrm{p}<.01$. Robust standard errors. 
Table 2 focuses on the model predicting scholastic Effort, $e_{i}^{*}$ in Equation (1): the first column reports the coefficients estimated on the exogenous explanatory variables in the baseline model (Note 9); additional explanatory variables are included in further specifications. Given that different factors influencing scholastic effort may be relevant especially for ethnic groups, for example, language usually spoken or English language mastery, it makes sense to consider only ethnic minorities; this is accomplished in Table 3. Tables 4 and 5 focus on individual Attitude towards school- $s_{i}$ in Equation 2-for the whole sample and ethnic minorities respectively.

Table 3. Ordered Probit Estimates of Scholastic Effort-Ethnic Groups

\begin{tabular}{|c|c|c|c|c|c|c|}
\hline & $\mathrm{I}$ & II & III & III & IV & $\mathrm{V}$ \\
\hline Age & $-0.056(0.064)$ & $-0.045(0.066)$ & $-0.043(0.067)$ & $-0.028(0.066)$ & $-0.023(0.066)$ & $-0.020(0.065)$ \\
\hline Female & $0.252 * * *(0.065)$ & $0.250 * * *(0.066)$ & $0.249 * * *(0.066)$ & $0.166 * *(0.067)$ & $0.238^{* * *}(0.067)$ & $0.249 * * *(0.068)$ \\
\hline Homework & $0.233^{* * *}(0.037)$ & $0.223 * * *(0.037)$ & $0.225 * * *(0.037)$ & $0.182 * * *(0.037)$ & $0.155 * * *(0.037)$ & $0.157 * * *(0.037)$ \\
\hline \multicolumn{7}{|l|}{ Ethnic group: } \\
\hline Gipsy & $-0.327(0.397)$ & $-0.318(0.395)$ & $-0.333(0.396)$ & $-0.341(0.361)$ & $-0.346(0.367)$ & $-0.273(0.349)$ \\
\hline Mixed & $-0.044(0.174)$ & $-0.028(0.177)$ & $0.036(0.177)$ & $0.101(0.185)$ & $-0.040(0.186)$ & $-0.026(0.019)$ \\
\hline Bangladeshi & $-0.124(0.196)$ & $-0.155(0.217)$ & $-0.168(0.223)$ & $-0.247(0.233)$ & $-0.193(0.235)$ & $-0.160(0.233)$ \\
\hline Chinese & $0.560 * *(0.347)$ & $0.759 * *(0.348)$ & $0.754 * *(0.348)$ & $0.720 *(0.390)$ & $0.843 * *(0.411)$ & $0.729 *(0.401)$ \\
\hline Pakistani & $0.042(0.183)$ & $-0.014(0.208)$ & $-0.028(0.213)$ & $-0.081(0.223)$ & $-0.005(0.224)$ & $0.016(0.224)$ \\
\hline Indians & $0.366^{* * *}(0.188)$ & $0.275 * *(0.233)$ & $0.270(0.233)$ & $0.212(0.238)$ & $0.247(0.236)$ & $0.229(0.250)$ \\
\hline Other Asians & $0.187(0.245)$ & $0.099(0.256)$ & $0.092(0.257)$ & $-0.021(0.254)$ & $0.058(0.253)$ & $0.060(0.252)$ \\
\hline$A r a b$ & $-0.093(0.211)$ & $0.045(0.216)$ & $-0.056(0.218)$ & $-0.103(0.229)$ & $-0.048(0.234)$ & $0.001(0.233)$ \\
\hline Black & $-0.283(0.187)$ & $-0.365 *(0.193)$ & $-0.378 * *(0.193)$ & $-0.436 * *(0.203)$ & $-0.372 *(0.200)$ & $-0.0(0.316)$ \\
\hline Other Ethnic Groups & $-0.231(0.277)$ & $-0.266(0.277)$ & $-0.262(0.276)$ & $-0.441(0.287)$ & $-0.403(0.289)$ & $-0.325 *(0.200)$ \\
\hline Victim & $-0.150 * *(0.072)$ & $-0.143^{* *}(0.072)$ & $-0.142 * *(0.072)$ & $-0.096(0.073)$ & $-0.035(0.072)$ & $-0.015(0.073)$ \\
\hline Language at home & $1.034 * *(0.463)$ & $0.976 * *(0.476)$ & $0.981 * *(0.476)$ & $1.022 * *(0.433)$ & $0.950 * *(0.441)$ & $1.035^{* *}(0.470)$ \\
\hline Language with friends & $0.059(0.039)$ & $0.039(0.038)$ & $0.039(0.038)$ & $0.041(0.038)$ & $0.048(0.038)$ & $0.055(0.038)$ \\
\hline Home*with friends & $-0.269 *(0.150)$ & $-0.253 *(0.152)$ & $-0.255^{*}(0.152)$ & $-0.243 *(0.142)$ & $-0.250 *(0.141)$ & $-0.280 *(0.145)$ \\
\hline Parents word test & $0.023(0.017)$ & $0.028(0.018)$ & $0.031 *(0.018)$ & $0.018(0.019)$ & $0.022(0.018)$ & $0.023(0.019)$ \\
\hline Teens word test & $-0.058(0.149)$ & $-0.005(0.015)$ & $-0.004(0.015)$ & $-0.017(0.016)$ & $-0.017(0.016)$ & $-0.019(0.016)$ \\
\hline Religious attend. & & $0.028(0.023)$ & $0.028(0.023)$ & $0.009(0.023)$ & $0.009(0.231)$ & $0.005(0.231)$ \\
\hline \multicolumn{7}{|l|}{ Religion: } \\
\hline Christian & & $1.051 * *(0.510)$ & $1.052 * *(0.507)$ & $1.158 * *(0.588)$ & $0.908 *(0.557)$ & $0.947 *(0.545)$ \\
\hline Muslim & & $0.984 * *(0.518)$ & $0.978 * *(0.522)$ & $1.025 *(0.604)$ & $0.737(0.574)$ & $0.758(0.563)$ \\
\hline Buddhist & & $0.114(0.630)$ & $0.120 *(0.634)$ & $0.117(0.721)$ & $-0.158(0.711)$ & $0.056(0.690)$ \\
\hline Hindu & & $1.212 * *(0.532)$ & $1.219 * *(0.537)$ & $1.236 * *(0.614)$ & $0.973 *(0.583)$ & $1.002 *(0.570)$ \\
\hline Sikh & & $1.003 *(0.539)$ & $1.006 *(0.544)$ & $1.045 *(0.623)$ & $0.790(0.591)$ & $0.160(0.220)$ \\
\hline Other religions & & $0.941(0.544)$ & $0.941(0.549)$ & $0.985(0.633)$ & $0.033(0.255)$ & $0.837(0.581)$ \\
\hline Income & & & & & $0.025(0.031)$ & $0.031(0.031)$ \\
\hline Wellfriends & & & & & $0.049(0.037)$ & $0.013(0.035)$ \\
\hline Wellfamily & & & & & & $0.087 * *(0.033)$ \\
\hline Wellschool & & & & $-0.344 * * *(0.037)$ & $-0.330 * * *(0.037)$ & $0.096 * * *(0.024)$ \\
\hline Peertrouble & & & & $0.334 * * *(0.037)$ & $0.308 * * *(0.037)$ & $-0.307 * * *(0.038)$ \\
\hline N. observations & 2326 & 2326 & 2326 & 2326 & 2326 & 2326 \\
\hline n. parameters & 24 & 34 & 35 & 39 & 42 & 43 \\
\hline Log-lik. & -1574.019 & -1561.904 & -1561.784 & -1496.999 & -1471.721 & -1459.100 \\
\hline Wald & 549.65 & 636.16 & 630.08 & 1270.23 & 754.21 & 806.74 \\
\hline
\end{tabular}

Notes: See Table 1 for the meaning of the variables. The reference group for ethnicity is non-UK White; the reference base group for religion is No religion. ${ }^{*} \mathrm{p}<0.10 ;{ }^{* *} \mathrm{p}<0.05 .{ }^{* * *} \mathrm{p}<.01$. Robust standard errors

As to the influence of Ethnicity (Note 10), the results are suggestive that ethnic background plays a role in motivating adolescents' scholastic effort. Indians and Chinese are more likely to exert effort than English teens, whereas for Black youth the opposite is true (Table 2- column I). The results in Table 3 (column I) confirm that teens with Chinese 
background as well as Indians are more oriented to scholastic effort than the other ethnic minorities considering non-UK White youth as the base group. These results may reflect the specificity of ethnic backgrounds and are partly in line with the evidence on Asians who generally give priority to good scholastic performance as they feel very responsible to their immigrant parents (Hirschman \& Lee 2005; Kao \& Thompson 2003). The result for Black adolescents who tend to exert lower effort, seems in accordance with Fordham and Ogbu (1986) who stress that African Americans may develop an oppositional identity. In the case of Attitude towards school (Tables 4-and 5, column I), Indians show higher interest in school both with respect to the UK group and non-UK Whites. Religion characterising ethnic background is included among the regressors in the second column; Islam, Christian, Hindu and Sikh religions promote both Scholastic Effort and Attitude towards School among ethnic minorities whereas attendance at religious services-identifying religious attachment- has a significant impact only in Table 5.

When teens speak also another language at home a part from English (Language at home), which may also mean attachment to ethnic background, there is a positive association with Effort and Attitude towards School. However, the coefficient on the interactive term Home*with friends (Note 11) in Table 3 shows a negative sign even if it is statistically significant only at ten percent. Interestingly, this evidence may point to a lower propensity to absorb mainstream culture if children speak a language different from English both at home and with friends; this has a detrimental effect only on Effort.

Further hints are provided by the coefficients on Teens' and Parents' word tests among ethnic minorities in Table 5, which are believed to capture the degree of adjustment to English culture. Overall word tests for teens and their parents as well as Language at home and Language with friends have positive and statistically significant coefficients thus showing that both the assimilation of mainstream culture through language mastery and the attachment to ethnic background are positively correlated with Attitude towards school. This evidence may reveal that teens do not perceive their cultural heritage and host culture as incongruent when they develop a deeper knowledge of English and at the same time speak their heritage language at home and with friends. Both aspects are believed to represent the mediation between teens' ethnic background and mainstream culture.

In the baseline model, in the subsample of ethnic minorities (Tables 3 and 5) attention paid by parents to children's homework (Homework) encourages them to exert effort, as for families' education paves the way for their children's socio-economic integration.

As to the other factors external to family's influence, particularly important is the variable Victim which reduces effort both in the whole sample and in the subsample of ethnic groups; as already stressed, one of the possible reasons is that the experience of strained relations with other groups and of social rejection undermines teen's development of cohesive identity and ultimately their motivations.

In order to fully single out the influence of the variables shaping individual attitude toward mainstream and heritage culture, we take into account family background. Family income (Income) positively influences Attitude towards School but the relative coefficient is not statistical significant in Tables 2-3. In effect, in our opinion, the influence of income can be controversial: on the one hand, teens with poor social origins may be more motivated to exert effort since they aspire to social mobility; on the other hand, high income and highly educated parents are more likely to foster their children's motivation to exert scholastic effort (Note 12).

\subsection{Further Specifications of the Model}

In the last columns of Tables 2-5, the full specification of the model is reported. We added other factors affecting adaptation to mainstream culture such as wellbeing related to family and friends (Wellfriends, Wellfamily) and the influence of peers (Peerhard, Peertrouble). In ethnic groups, teens' happiness with their family- Wellfamily- shows a positive effect on Effort and Attitude towards School; it may also indicate that conflicts related to different attitudes toward English culture between parents and children are not prevailing in daily family life. Often such conflicts are due to conservative parents who are more attached to their home culture, which usually leads to different views on the responsibility for various chores. The coefficient estimated on Peerhard shows a positive association between the increasing proportion of peers working hard and teens' effort, which may foster their motivation in school by helping the absorption of mainstream culture and the development of a more cohesive identity; not surprisingly, we report a negative coefficient on Peertrouble (Note 13). 
Table 4. Ols Estimates of Attitude towards School-Whole Sample

\begin{tabular}{|c|c|c|c|c|c|c|}
\hline & $\mathrm{I}$ & II & III & III & IV & $\mathrm{V}$ \\
\hline Age & $-0.105(0.056)$ & $-0.076(0.062)$ & $-0.082(0.062)$ & $-0.058(0.058)$ & $-0.051(0.057)$ & $-0.029(0.054)$ \\
\hline Female & $0.142(0.053)$ & $-0.007(0.058)$ & $-0.003(0.057)$ & $-0.198 * * *(0.055)$ & $-0.129 * *(0.055)$ & $-0.077(0.052)$ \\
\hline Homework & $0.427 * * *(0.032)$ & $0.474 * * *(0.033)$ & $0.454 * * *(0.033)$ & $0.340 * * *(0.032)$ & $0.289 * * *(0.031)$ & $0.265 * * *(0.029)$ \\
\hline \multicolumn{7}{|l|}{ Ethnic group: } \\
\hline White & $-0.052(0.269)$ & $-0.030(0.275)$ & $-0.077(0.285)$ & $0.094(0.284)$ & $0.050(0.280)$ & $0.012(0.277)$ \\
\hline Gipsy & $0.186(0.596)$ & $-0.228(0.733)$ & $-0.099(0.744)$ & $-0.006(0.517)$ & $-0.038(0.494)$ & $0.189(0.395)$ \\
\hline Mixed & $0.057(0.118)$ & $-0.137(0.145)$ & $-0.111(0.144)$ & $-0.106(0.135)$ & $-0.073(0.132)$ & $-0.060(0.122)$ \\
\hline Bangladeshi & $-0.146(0.178)$ & $-0.441(0.239)$ & $-0.339(0.237)$ & $-0.399 *(0.219)$ & $-0.381 *(0.215)$ & $-0.331 *(0.204)$ \\
\hline Chinese & $0.470(0.546)$ & $0.922 * *(0.438)$ & $0.924 * *(0.454)$ & $0.976 *(0.575)$ & $1.072 *(0.619)$ & $0.556(0.542)$ \\
\hline Pakistani & $0.475 * * *(0.144)$ & $0.011(0.222)$ & $0.115(0.221)$ & $0.063(0.203)$ & $0.093(0.196)$ & $0.103(0.191)$ \\
\hline Indian & $0.647 * * *(0.150)$ & $-0.037(0.281)$ & $-0.048(0.278)$ & $-0.050(0.243)$ & $-0.079(0.247)$ & $-0.214(0.233)$ \\
\hline Other Asians & $0.790 * *(0.234)$ & $0.182(0.333)$ & $0.188(0.338)$ & $0.062(0.296)$ & $0.109(0.289)$ & $0.022(0.286)$ \\
\hline Arabs & $-0.101(0.229)$ & $-0.076(0.236)$ & $-0.018(0.234)$ & $0.013(0.234)$ & $0.038(0.226)$ & $0.182(0.226)$ \\
\hline Black & $0.068(0.138)$ & $-0.272 *(0.170)$ & $-0.187(0.173)$ & $-0.165(0.172)$ & $-0.132(0.162)$ & $0.037(0.152)$ \\
\hline Other Ethnic Groups & $-0.123(0.338)$ & $-0.009(0.327)$ & $-0.108(0.320)$ & $-0.296(0.305)$ & $-0.277 * * *(0.055)$ & $-0.369(0.273)$ \\
\hline Victim & $-0.450 * * *(0.055)$ & $-0.544 * * *(0.059)$ & $-0.533 * * *(0.059)$ & $-0.359 * * *(0.056)$ & $-0.890 * *(0.452)$ & $-0.184 * * *(0.053)$ \\
\hline Language at home & $1.100 * *(0.471)$ & $1.227 * *(0.056)$ & $1.234 * *(0.493)$ & $0.117 * *(0.448)$ & $0.109 * *(0.051)$ & $1.133 *(0.611)$ \\
\hline Language with friends & $0.178 * * *(0.056)$ & $0.114 * * *(0.058)$ & $0.115 * *(0.056)$ & $0.109 * *(0.053)$ & $0.157(0.167)$ & $0.128 * *(0.049)$ \\
\hline Home*with friends & $-0.224(0.231)$ & $-0.266(0.202)$ & $-0.256(0.207)$ & $-0.175(0.169)$ & $-0.156(0.167)$ & $-0.242(0.199)$ \\
\hline Parents word test & $0.063 * * *(0.015)$ & $0.083 * * *(0.016)$ & $0.046 * *(0.016)$ & $0.021(0.015)$ & $0.025 *(0.015)$ & $0.019(0.014)$ \\
\hline Teens word test & $0.077 * * *(0.012)$ & $0.081 * * *(0.012)$ & $0.073 * *(0.012)$ & $0.041 * * *(0.012)$ & $0.040 * * *(0.012)$ & $0.029 * *(0.011)$ \\
\hline Religious attend. & & $0.131 * * *(0.025)$ & $0.365(0.302)$ & $0.106 * * *(0.023)$ & $0.104 * * *(0.023)$ & $0.084 * * *(0.022)$ \\
\hline \multicolumn{7}{|l|}{ Religion: } \\
\hline Christians & & $0.273(0.308)$ & $0.365(0.302)$ & $0.144(0.317)$ & $0.076(0.298)$ & $0.155(0.267)$ \\
\hline Muslim & & $0.456(0.355)$ & $0.639 *(0.349)$ & $0.289(0.356)$ & $0.180(0.336)$ & $0.220(0.307)$ \\
\hline Buddhism & & $-1.284 * *(0.641)$ & $-1.185^{*}(0.643)$ & $-1.622 * *(0.551)$ & $-1.744 * *(0.585)$ & $-0.919 *(0.486)$ \\
\hline Hindu & & $0.941 * *(0.430)$ & $0.979 * *(0.426)$ & $0.570(0.419)$ & $0.515(0.402)$ & $0.568(0.367)$ \\
\hline Sikh & & $0.989 * *(0.439)$ & $1.085 * *(0.434)$ & $0.707 *(0.432)$ & $0.659(0.417)$ & $0.777 * *(0.393)$ \\
\hline Other religions & & $0.370(0.373)$ & $0.508(0.374)$ & $0.317(0.391)$ & $0.233(0.373)$ & $0.294(0.353)$ \\
\hline Income & & & $0.155^{* * *}(0.024)$ & $0.109 * * *(0.023)$ & $0.099 * * *(0.023)$ & $0.067 * * *(0.022)$ \\
\hline Peertrouble & & & & $-0.713 * * *(0.032)$ & $-0.685^{* * *}(0.031)$ & $-0.603 * * *(0.030)$ \\
\hline Peerhard & & & & $0.697 * * *(0.032)$ & $0.648 * * *(0.032)$ & $0.579 * * *(0.031)$ \\
\hline Wellfriends & & & & $0.334 * * *(0.037)$ & $0.101 * * *(0.029)$ & $0.064 * *(0.031)$ \\
\hline Wellfamily & & & & & $0.143 * * *(0.029)$ & $0.065 * *(0.029)$ \\
\hline Wellschool & & & & & & $0.405 * * *(0.025)$ \\
\hline N. observations & 7893 & 7893 & 7893 & 7893 & 7893 & 7893 \\
\hline n. parameters & 24 & 34 & 35 & 39 & 42 & 43 \\
\hline F-stat & 17.70 & 17.91 & 17.96 & 34.73 & 37.93 & 48.63 \\
\hline R-squared & 0.10 & 0.12 & 0.13 & 0.23 & 0.25 & 0.31 \\
\hline
\end{tabular}

Notes: See Table 1 for the meaning of the variables. The reference group for ethnicity is UK; the reference base group for religion is No religion. ${ }^{*} \mathrm{p}<0.10 ; * * \mathrm{p}<0.05$. ${ }^{* * *} \mathrm{p}<.01$. Robust standard errors 
Table 5. Ols Estimates of Attitude towards School- Ethnic Groups

\begin{tabular}{|c|c|c|c|c|c|c|}
\hline & $\mathrm{I}$ & II & III & III & IV & V \\
\hline Age & $-0.076(0.124)$ & $-0.032(0.119)$ & $-0.049(0.118)$ & $-0.011(0.111)$ & $-0.005(0.109)$ & $0.008(0.105)$ \\
\hline Female & $0.129(0.119)$ & $0.129(0.117)$ & $0.136(0.117)$ & $-0.070(0.111)$ & $0.041(0.108)$ & $0.077(0.103)$ \\
\hline Homework & $0.404 * * *(0.064)$ & $0.352 * * *(0.063)$ & $0.341 * * *(0.063)$ & $0.229 * * *(0.060)$ & $0.183 * * *(0.057)$ & $0.183 * * *(0.056)$ \\
\hline \multicolumn{7}{|l|}{ Ethnic group: } \\
\hline Gipsy & $-0.339(0.795)$ & $-0.256(0.784)$ & $-0.116(0.794)$ & $-0.092(0.602)$ & $-0.098(0.588)$ & $0.136(0.510)$ \\
\hline Mixed & $-0.104(0.309)$ & $-0.101(0.308)$ & $-0.038(0.313)$ & $-0.175(0.315)$ & $-0.043(0.308)$ & $0.002(0.305)$ \\
\hline Bangladeshi & $-0.173(0.333)$ & $-0.451(0.352)$ & $-0.332(0.363)$ & $-0.507(0.358)$ & $-0.409(0.352)$ & $-0.304(0.345)$ \\
\hline Chinese & $0.566(0.604)$ & $0.950 * *(0.499)$ & $1.001 * *(0.507)$ & $0.922(0.637)$ & $1.096 *(0.689)$ & $0.741(0.618)$ \\
\hline Pakistani & $0.383(0.319)$ & $-0.032(0.343)$ & $0.090(0.353)$ & $-0.069(0.349)$ & $0.060(0.341)$ & $0.123(0.337)$ \\
\hline Indian & $0.608 *(0.323)$ & $-0.020(0.381)$ & $0.022(0.384)$ & $-0.127(0.370)$ & $-0.083(0.371)$ & $-0.148(0.363)$ \\
\hline Other Asians & $0.480(0.412)$ & $0.051(0.426)$ & $0.110(0.434)$ & $-0.153(0.414)$ & $-0.044(0.404)$ & $-0.043(0.401)$ \\
\hline Arab & $-0.069(0.369)$ & $-0.021(0.367)$ & $0.073(0.376)$ & $-0.047(0.377)$ & $0.050(0.370)$ & $0.207(0.367)$ \\
\hline Black & $-0.024(0.329)$ & $-0.367(0.333)$ & $-0.262(0.342)$ & $-0.352(0.346)$ & $-0.242(0.332)$ & $-0.074(0.327)$ \\
\hline Other Ethnic Groups & $0.013(0.440)$ & $-0.139(0.442)$ & $-0.169(0.443)$ & $-0.510(0.438)$ & $-0.449(0.434)$ & $-0.476(0.419)$ \\
\hline Victim & $-0.479 * * *(0.132)$ & $-0.441 * * *(0.129)$ & $-0.450 * * *(0.130)$ & $-0.335 * * *(0.124)$ & $-0.233 * *(0.120)$ & $-0.173(0.114)$ \\
\hline Language at home & $1.441 * *(0.744)$ & $1.328 *(0.766)$ & $1.282 *(0.760)$ & $1.306 *(0.717)$ & $1.196(0.768)$ & $1.362 *(0.852)$ \\
\hline Language with friends & $0.223 * * *(0.065)$ & $0.130 * *(0.061)$ & $0.132 * *(0.061)$ & $0.132 * *(0.057)$ & $0.139 * *(0.055)$ & $0.154 * *(0.053)$ \\
\hline Home*with friends & $-0.307(0.266)$ & $-0.284(0.249)$ & $-0.266(0.250)$ & $-0.223(0.226)$ & $-0.221(0.236)$ & $-0.279(0.255)$ \\
\hline Parents word test & $0.059 *(0.033)$ & $0.078 * *(0.033)$ & $0.058 *(0.033)$ & $0.030(0.031)$ & $0.032(0.028)$ & $0.036(0.028)$ \\
\hline Teens word test & $0.074 * * *(0.025)$ & $0.057 * *(0.024)$ & $0.051 * *(0.024)$ & $0.024(0.024)$ & $0.022(0.022)$ & $0.013(0.022)$ \\
\hline Religious attend. & & $0.170 * * *(0.040)$ & $0.167 * * *(0.040)$ & $0.126 * * *(0.037)$ & $0.113 * * *(0.037)$ & $0.112 * * *(0.034)$ \\
\hline \multicolumn{7}{|l|}{ Religion: } \\
\hline Christian & & $1.498 * * *(0.483)$ & $1.546 * * *(0.485)$ & $1.687 * * *(0.464)$ & $1.660 * * *(0.504)$ & $1.057 * *(0.396)$ \\
\hline Muslim & & $1.542 * * *(0.481)$ & $1.644 * * *(0.483)$ & $1.682 * * *(0.453)$ & $1.587 * * *(0.493)$ & $0.944 * *(0.390)$ \\
\hline Hindu & & $2.111 * * *(0.526)$ & $2.102 * * *(0.527)$ & $2.017 * * *(0.499)$ & $1.971 * * *(0.527)$ & $1.346^{* *}(0.422)$ \\
\hline Sikh & & $2.063 * * *(0.533)$ & $2.095^{* * *}(0.534)$ & $2.089 * * *(0.517)$ & $2.050 * * *(0.547)$ & $1.478 * * *(0.45)$ \\
\hline Other religions & & $1.895 * * *(0.584)$ & $1.953 * * *(0.593)$ & $1.944 * * *(0.577)$ & $1.798 * * *(0.613)$ & $1.089 * *(0.515)$ \\
\hline Income & & & $0.112 * *(0.053)$ & $0.099 * *(0.050)$ & $0.090 *(0.049)$ & $0.073(0.046)$ \\
\hline Peertrouble & & & & $-0.712 * * *(0.059)$ & $-0.674 * * *(0.059)$ & $-0.594 * * *(0.055)$ \\
\hline Peerhard & & & & $0.667 * * *(0.058)$ & $0.601 * * *(0.058)$ & $0.543 * * *(0.055)$ \\
\hline Wellfriends & & & & & $0.151 * *(0.061)$ & $0.030(0.060)$ \\
\hline Wellfamily & & & & & $0.141 * *(0.052)$ & $0.078(0.053)$ \\
\hline Wellschool & & & & & & $0.309 * * *(0.047)$ \\
\hline N. observations & 2320 & 2320 & 2320 & 2320 & 2320 & 2320 \\
\hline n. parameters & 25 & 35 & 36 & 36 & 43 & 44 \\
\hline Log-lik. & 6.99 & 8.42 & 9.55 & 12.35 & 13.42 & 16.09 \\
\hline Wald & 0.12 & 0.16 & 0.16 & 0.26 & 0.29 & 0.34 \\
\hline
\end{tabular}

Notes: See Table 1 for the meaning of the variables. The reference group for ethnicity is non-UK White; the reference base group for religion is No religion. ${ }^{*} \mathrm{p}<0.10 ; * * \mathrm{p}<0.05$. $* * * \mathrm{p}<.01$. Robust standard errors

Another factor that can play a key role in youth's adaptation to English culture is wellbeing in school (Wellschool) whose coefficient is positive and strongly significant in all the specifications of the model (Note 14); it is believed to represent also the quality of social relationships in school, which may partly be related to dominant groups orientations towards ethnic groups and to youth's experience of social acceptance (Note 15).

On the whole, the evidence presents the possibility that ethnicity matters and that in some cases it weakens the motivation to exert scholastic effort. The latter result in our view indirectly reveals some discrepancies between ethnic and mainstream culture, which undermine the development of teens' cohesive identity (Note 16). Nevertheless, our evidence also shows that such effect can be mitigated by religion-another component of ethnic background-and some other factors affecting the absorption of mainstream culture like, for instance, attention paid by parents to children's 
homework or wellbeing in school. It is also true that the experience of strained relations with other groups and of social rejection may exacerbate the contrast between ethnic background and mainstream culture perceived by teens.

\section{Concluding Remarks}

In this paper the choice of scholastic effort is modelled by taking explicitly into account orientations of immigrants' children toward mainstream and heritage culture. In particular, later-generation descendants of immigrants learn both cultures simultaneously; this crucial aspect implies that individuals have to negotiate the two cultures and bridging the gap between them may become particularly problematic when they are perceived as distant. Such distance may depend on specific aspects of ethnic cultural background that generally parents transmit on to their children, on peers' influence and importantly on the experience of strained relations, social rejection and discrimination.

Empirical evidence is suggestive that ethnic background plays a role in motivating adolescents' scholastic effort and shows that Chinese and Indians are more likely to exert effort than English youth, whereas for Black youth the opposite is true; Chinese also show higher interest in school both with respect to the UK group and non-UK Whites. In our view, when ethnicity weakens the motivation to exert scholastic effort, it may indirectly reveal some discrepancies between ethnic and mainstream culture, which undermine the development of teens' cohesive identity. Importantly, the use of language is one of the key forces behind the process of integration; in this respect, the evidence indicates that both adjustment to English culture through language mastery and attachment to ethnic background through the use of their heritage language at home or with friends are positively correlated with youth's interest in school. Such effect may be driven by the perception that ethnic and dominant cultures are not distant. The experience of social rejection and strained relations with other groups determines a negative influence on effort, as it probably nurtures the feeling of distance between the two cultures. On the whole, the evidence may show the possibility that all the factors that help the mediation between ethnic background and mainstream culture by promoting the development of a cohesive identity foster the motivation of scholastic effort.

\section{References}

Autiero, G., \& Nese, A. (2017). Ethnic and Academic Identity: What Role for Children's Scholastic Effort? Forum for Social Economics, 50(1), 1-21. https://doi.org/10.1080/07360932.2017.1394899

Autiero, G., \& O'Higgins, N. S. (2016). Jailer of freedom and enemy of growth? International Review of Applied Economics, 30(5), 591-604. https://doi.org/10.1080/02692171.2016.1146874.

Benet-Martìnez, V., Leu, J., Lee, F., \& Morris, M. W. (2002). Negotiating biculturalism: Cultural frame-switching in biculturals with oppositional vs. compatible cultural identities. Journal of Cross-Cultural Psychology, 33(5), 492-516. https://doi.org/10.1177/0022022102033005005

Benet-Martìnez, V., \& Hritatos, J. (2005). Bicultural Identity Integration (BII): Components and Psychosocial Antecedents. Journal of Personality, 73(4), 1015-1050. https://doi.org/10.1111/j.1467-6494.2005.00337.x

Berry, J. W. (2005). Acculturation: Living successfully in two cultures. International Journal of Intercultural Relations, 29(6), 697-712. https://doi.org/10.1016/j.ijintrel.2005.07.013

Bisin, A., \& Verdier, T. (2000). Beyond the Melting Pot: Cultural Transmission, Marriage and the Evolution of Ethnic and Religious Traits. The Quarterly Journal of Economics, 115, 955-988. https://doi.org/10.1162/003355300554953

Bisin, A., \& Verdier, T. (2001). The Economics of Cultural Transmission and the Dynamics of Preferences. Journal of Economic Theory, 97, 298-319. https://doi.org/10.1006/jeth.2000.2678

Bisin, A., \& Verdier, T. (2011). The Economics of Cultural Transmission and Socialization. In J. Benhabib, A. Bisin, \& M. O. Jackson (Eds.), Handbook of Social Economics, 1A, 339-416. The Netherlands: North-Holland. https://doi.org/10.1016/B978-0-444-53187-2.00009-7

Bisin, A., Patacchini, E., Verdier, T., \& Zenou, Y. (2016). Bend It Like Beckham: Ethnic Identity and Integration. European Economic Review, 90(C), 146-164. https://doi.org/10.1016/j.euroecorev.2016.01.006

Brown, R. (2000). Social identity theory: Past achievements, current problems, and future challenges. European $\begin{array}{lllll}\text { Journal of } & \text { Social } & \text { Psychology, } & 30, & \text { 745-778. }\end{array}$ https://doi.org/10.1002/1099-0992(200011/12)30:6<745::AID-EJSP24>3.0.CO;2-O 
Dustmann, C., \& Theodoropoulos, N. (2010). Ethnic minority immigrants and their children in Britain. Oxford Economic Papers, 62(2), 209-233. https://doi.org/10.1093/oep/gpq004

Fernàndez, R. (2010). Does Culture Matter? NBER Working Paper, No. 16277, 1-42. https://doi.org/10.3386/w16277

Fernàndez, R. (2008). Culture and Economics. In S. N. Durlauf, \& L. E. Blume (Eds.), the New Palgrave Dictionary of Economics (2nd ed.), 1-9. Palgrave Macmillan. https://doi.org/10.1057/978-1-349-95121-5_2192-1

Fordham, S., \& Ogbu, J. U. (1986). Black Students' School Success: Coping with the Burden of Acting White. The Urban Review, 18(3), 176-206. https://doi.org/10.1007/BF01112192

Giavazzi, F., Petkov, I., \& Schiantarelli, F. (2019). Culture: persistence and evolution. Journal of Economic Growth, 24(2), 117-154. https://doi.org/10.1007/s10887-019-09166-2.

Huynh, Que-Lam, N., Angela-MinhTu, D., \& Benet-Martínez, V. (2001). Bicultural Identity Integration. In S. J. Schwartz, K. Luyckx, \& V. L. Vignoles (Eds.), Handbook of Identity Theory and Research (pp. 827-842). New York, NY, Springer. https://doi.org/10.1007/978-1-4419-7988-9_35

Jensen, L. A. (2003). Coming of age in a multicultural world: Globalization and adolescent cultural identity formation. Applied Developmental Science, 7, 189-196. https://doi.org/10.1207/S1532480XADS0703_10

Konya, I. (2005). Minorities and Majorities: A Dynamic Model of Assimilation. Canadian Journal of Economics, 38(4), 1431-1452. https://doi.org/10.1111/j.0008-4085.2005.00331.x

Lazear, E. P. (1999). Culture and Language. Journal of Political Economy, 107(6), 95-126. https://doi.org/10.1086/250105

Maestri, V. (2013). Promoting scientific faculties. Does it work? Evidence from Italy. Economics of Education Review, 32(1), 168-180. https://doi.org/10.1016/j.econedurev.2012.10.003

Manski, C. F. (1993). Identification of Endogenous Social Effects: The Reflection Problem. The Review of Economic Studies, 60(3), 531-542. https://doi.org/10.2307/2298123

Matthews, J. S., Banerjee, M., \& Lauermann, F. (2014). Academic identity formation and motivation among ethnic minority adolescents: The role of the "self" between internal and external perceptions of identity. Child Development, 85, 2355-2373. https://doi.org/10.1111/cdev.12318

Meunier, M., de Coulon, A., \& Marcenaro-Gutierrez, O. (2013). A longitudinal analysis of UK second-generation $\begin{array}{lllll}\text { disadvantaged } \quad \text { immigrants. } & \text { Education } & \text { Economics, } & 21(2), & 105-134 .\end{array}$ https://doi.org/10.1080/09645292.2011.568605

Nekby, L., Rödin, M., \& Özcan, G. (2009). Acculturation Identity and Higher Education: is there a Trade-off between Ethnic Identity and Education? International Migration Review, 43(4), 938-973. https://doi.org/10.1111/j.1747-7379.2009.00790.x

Nguyen, Angela-MinhTu, D., \& Benet-Martínez, V. (2013). Biculturalism and Adjustment: A Meta-Analysis. Journal of Cross-Cultural Psychology, 44(1), 122-159. https://doi.org/10.1177/0022022111435097

Portes, A., \& Zhou, M. (1993). The new second generation: segmented assimilation and its variants. Annals of the American Academy of Political and Social Science, 530, 74-96. https://doi.org/10.1177/0002716293530001006

Portes, A., \& Rumbaut, R. G. (2001). Legacies: The story of the immigrant second generation. Berkeley: University of California Press.

Rudmin, F. W. (2003). Critical history of the acculturation psychology of assimilation, separation, marginalization, and integration. Review of General Psychology, 7, 3-37. https://doi.org/10.1037/1089-2680.7.1.3

Schüller, S. (2015). Parental ethnic identity and educational attainment of second-generation immigrants. Journal of Population Economics, 28(4), 965-1004. https://doi.org/10.1007/s00148-015-0559-7

Siahaan, F., Lee, D. Y., \& Kalist, D. E. (2014). Educational attainment of children of immigrants: Evidence from the national longitudinal survey of youth. Economics of Education Review, 38, 1-8. https://doi.org/10.1016/j.econedurev.2013.10.001

Yasui, M., \& Dishion, T. (2007). The Ethnic Context of Child and Adolescent Problem Behavior: Implications for Child and Family Interventions. Clinical Child and Family Psychology Review, 10(2), 137-79. https://doi.org/10.1007/s10567-007-0021-9 


\section{Notes}

Note 1. In England, the population was divided in three strata: the ethnic minority stratum; the disadvantaged stratum and the advantaged stratum. In Wales, Scotland and Northern Ireland there were only the last two strata because of the low percentages of ethnic minorities.

Note 2. Referring to "main" parent (i.e. who mainly took part to the interview), out of 2200 individuals 853 are British-born, 1119 are foreign-born and for the remaining part there is no information. Referring to main parent's partner, 864 are foreign-born, 853 are British-born and for 524 there is no information.

Note 3. The reasons that determined migration (e.g., political, economic reasons, etc.) and migrants' socio-economic conditions presumably vary by country and point of time in history. As we will see later in the paper, the inclusion of parental background among the correlates further reduces any selection problems.

Note 4. The 1970 British Cohort Study does not allow explicit measures of scholastic effort as it contains the following questions: (1) I feel school is a waste of time; (2) I don't like school; (3) I think homework is a bore; (4) I find it difficult to keep my mind on my work; (5) I never take work seriously; (6) I am quiet in classroom and get on with my work.

Note 5. Taking into account that the assumption of normality could be too strong, for robustness purposes, we also run linear regression and the results - available on request- were consistent with the ordered probit estimates.

Note 6. The Cronbach's reliability coefficient Alpha for this index was 0.70 . Factor analysis also confirmed the relationship between the observed variables and an underlying construct that we interpret as scholastic motivation. The estimate of an ordered probit is problematic as too many thresholds have to be estimated.

Note 7. Out of 2200 main parents 1119 are foreign-born (see also note 2 on this point). Parents with a high level of education or income encourage their children's education, however parents' education embodies also beliefs and preferences that they transmit to their children and may differ across ethnic minorities.

Note 8. Parents' word test is obtained as an average between mother's and father's word tests. See the Legend in Table 1 for more details about the word tests taken by teens and parents.

Note 9. In previous estimates, early ability - evaluated at age three according to the British Ability Scales-was included among the regressors but we reported no significant evidence. In our opinion, the influence of ability can be controversial: on the one hand, it should encourage higher effort of able pupils who aspire to ambitious results; on the other hand, low ability may require more effort in order to achieve specific scholastic goals.

Note 10. The results on Mixed are hardly interpretable given the largely missing information on parents' ethnic background.

Note 11. The variable Home*with friends is obtained by interacting Language at home with Language with friends.

Note 12. In previous estimates - available on request - we also included main parent's academic qualification (evaluated according to the National Vocational Qualifications) and found that it was highly correlated with family income. In fact, the relative coefficient was positive and statistical significant in the model estimating Attitude towards School only when income was not included among the regressors.

Note 13. Once again, however, it is important to underline that our estimates probably are biased by both reflection problem and endogeneity (Mansky, 1993).

Note 14. Some concern remains about the exogeneity of Wellschool, particularly in the model predicting attitude towards school as one could reasonably argue that individuals more positively oriented to school are also more likely to feel good at school and vice versa.

Note 15. Previous literature has highlighted that the share of ethnic minority students in school affects pupils of ethnic minorities, while the effect is relatively modest for native children (Maestri, 2013; Autiero \& Nese, 2017). Unfortunately, we do not have information on ethnic heterogeneity in teens' school environment.

Note 16. The available ethnic sample size did not permit further investigation into the observed differences among ethnic minorities 


\section{Copyrights}

Copyright for this article is retained by the author(s), with first publication rights granted to the journal.

This is an open-access article distributed under the terms and conditions of the Creative Commons Attribution license (http://creativecommons.org/licenses/by/4.0/). 